\title{
RAGAM BAHASA GAUL DI PASAR DAN TERMINAL BOJONEGORO
}

\author{
Abdul Syukur \\ SMP Negeri 2 Sumberrejo, Bojonegoro \\ Pos-el asyukur6741@yahoo.co.id
}

\begin{abstract}
Abstrak: Penelitian ini bertujuan untuk mendeskripsikan kosa kata berdasarkan perubahan struktur fonologis, morfologi, dan sintaksis bahasa gaul yang digunakan masyarakat pasar dan terminal Bojonegoro. Data dikumpulkan dengan observasi berbentuk teknik sadap, simak, pancing dan catat. Metode dan teknik analisis data adalah metode deskriptif kualitatif dan teknik distribusional. Hasil penelitian ini sebagai berikut. Pertama perubahan struktur fonologis bahasa gaul. Kedua, proses morfologis kosakata bahasa gaul meliputi a) akronim dibentuk dari dua suku kata awal akhir dari dua kata, dua suku kata awal dari dua kata, empat suku kata awal dari empat kata, b) afiksasi, c) reduplikasi, d) sisipan -ok-e) akhiran -ong dan -ing vokal dan konsonan.
\end{abstract}

Kata Kunci: bahasa gaul, perubahan struktur fonologis, proses pembentukan secara morfologis

Abstract: This study aimed to describe the vocabulary based on change in the structure of the phonology, morphology, syntax and slang used bojonegoro society in the terminals and markets. Data collected by observation shaped tapping techniques, see, fishing rods and record. Method and data analysis is qualitative descriptive method and technique of distributional. The results of this study as follows. The first, phonological structure change slang. The second, the process of formation of morphologically vocabulary of slang include a) acronyms formed of two syllables beginning of the from the two words, two syllable the beginning of the two words, four syllables beginning of four words, b) affixation, c) reduplication d) inset-ok-e) suffix-ong and-ing vowel and consonant.

Keyword: slang, changes in the structure of the phonological, mophological formation

\section{PENDAHULUAN}

Menurut Danandjaja (dalam Sahertian, 2002: 5), bahasa gaul adalah salah satu bentuk (genre) folklore yang disebut "ujaran rakyat" (folk speech). Dalam ujaran rakyat, ia termasuk dalam bentuk yang disebut slang (ucapan populer). Sebagai konteks dari bahasa gaul, kosakata inilah yang berperan penting dalam perkembangan bahasa gaul. Para remaja cenderung menciptakan kosakata baru yang menggelitik dan "aneh". Remaja berkreativitas menggunakan tutur remaja yang khas dan bersifat informal karena dianggap lebih mudah untuk proses berkomunikasi. 
Terkadang, para remaja tidak mengetahui asal-usul kosakata bahasa gaul bahkan maknanya. Bagi mereka yang terpenting kosakata tersebut sedang menjadi trend dan terasa "berbeda", maka kosakata tersebut akan digunakan. Perkembangan atau perubahan kosakata bahasa Indonesia yang dipengaruhi oleh media massa telah memberikan sumbangan yang signifikan terhadap aspek leksikal maupun gramatikal yang ada dalam pembentukan kosakata bahasa Indonesia. Sumbangan tersebut misalnya ejaan, gaya bahasa, gramatika, kosakata, dan sebagainya.

Perkembangan lain ditandai dengan munculnya kosakata serapan bahasa asing atau dari bahasa daerah itu sendiri, misalnya kata so what gitu lo yang berasal dari bahasa Inggris yang berarti 'lalu kenapa', makdirabit yang sering digunakan oleh orang Betawi yang berarti umpatan 'sialan' Munculnya kosakata baru juga disebabkan oleh kekurangan kosakata dalam perbendaharaan bahasa Indonesia (Sutami dan Wrihatni, 2008). Hal tersebut mengakibatkan generasi muda melakukan perubahan kosakata sebelumnya atau menyerap kosakata asing tanpa penyesuaian secara fonologis maupun morfologis. Padahal sebenarnya, kosakata tersebut masih bias ditemukan padanan kosakata dalam bahasa Indonesia.

Kosakata bahasa gaul dapat pula membentuk istilah baru yang sesuai dengan kaidah bahasa Indonesia (Sutami dan Wrihatni, 2008). Akan tetapi, demi kemudahan dan kenyamanan dalam berkomunikasi menggunakan kosakata bahasa gaul, maka mereka menciptakan kosakata bahasa gaul yang lebih bervariasi dan lebih kekinian.Kasus perkembangan kosakata bahasa gaul ini mengalami perubahan daritahun ke tahun yang dapat dilihat dari segi fonologis, morfologis dan sintaksis. Perubahan pembentukan kosakata baru tersebut telah melalui proses peminjaman, penciptaan kosakata baru, bahkan penyerapan dari bahasa asing dan bahasa daerah.

Kenyataan bahwa bahasa terus berkembang dan berubah pada zaman sekarang, dapat dilihat misal kata "ame" pada tahun 1990-an bisa berubah menjadi kata "ama/ame" di tahun 2000-an, sedangkan kata "kamseu" pada tahun 2000-an menjadi kamseupay pada tahun 2009-an. Apabila merunut tentang sejarah bahasa gaul, perubahan bahasa yang terjadi misalnya, pada era 90-an menggunakan istilah bahasa prokem, kemudian diakhir era 90-an, muncul fenomena bahasa gaul yang dipopulerkan oleh Debby Sahertian. Bahasa gaul berkembang lagi pada tahun 2009 menjadi bahasa alay. Bahasa alay ini menjadi tren ketika era komunikasi semakin berkembang, mulai dari media cetak atau media elektronik. Misalnya, yang sedang menjadi tren sekarang adalahpenggunaan bahasa "instagram" (penggunaan tanda '\#' hashtag) yang menjamur sebagai akibat dari maraknya penggunaan jejaring sosial, seperti instagram dan twitter.Fenomena perubahan bahasa dari tahun ke tahun inilah yang menarik untuk dianalisis lebih lanjut. Hal ini karena penginterpretasian terhadap kosakata bahasa gaul masih jarang ditemukan pada penelitianpenelitian yang sudah ada mengenai bahasa gaul. Oleh karena itu, peneliti dituntut untuk dapat membuka wawasan dan serta mengangkat masalah kebahasaan terutama mengenaikosakata.

Penelitian ini memiliki tujuan mendeskripsikan (1) struktur fonologis kosakata dan (2) pembentukan kosakata bahasa gaul secara morfologis dalam bahasa gaul di pasar dan terminal di Bojonegoro. 
Teori yang digunakan untuk mendukung penelitian ini merupakan teori gabungan dari para ahli bahasa. Pemilihan teori dalam penelitian ini dengan mempertimbangkan hubungan yang relevan terhadap masalah yang akan diteliti, yaitu bahasa gaul di kalangan masyarakat pasar dan terminal. Teoriteori tersebut adalah hakikat bahasa, konsep teori sosiolinguistik, variasi bahasa dan ragamnya, bahasa gaul, proses pembentukan kata secara morfologis, tipe-tipe perubahan struktur kata secara fonologis, makna kata, dan penelitian yang relevan.

Bahasa adalah alat komunikasi yang paling baik dan paling sempurna dibanding dengan alat-alat komunikasi yang lain. Bahasa mempunyai ciri sebagai alat interaksi sosial dan sebagai alat mengidentifikasi diri. Dengan bahasa, orang dapat mengungkapkan pikiran, perasaan dan kemauannya kepada orang lain dalam suatu kelompok masyarakat. Bahasa adalah suatu sistem lambang bunyi, bersifat arbitrer, digunakan oleh suatu masyarakat tutur untuk bekerja sama, berkomunikasi dan mengidentifikasi diri. Setiap bahasa mempunyai pola dan aturan-aturan tertentu dalam hal tata bunyi, kata, kalimat, dan makna. Berbagai faktor yang terdapat di dalam masyarakat pemakai bahasa, seperti usia, pendidikan, agama, profesi dan latar belakang budaya daerah, juga bisa menyebabkan adanya keragaman bahasa.

Secara umum sosiolinguistik membahas hubungan bahasa dengan penutur bahasa sebagai anggota masyarakat. Hal ini mengaitkan fungsi bahasa secara umum yaitu sebagai alat komunikasi. Sosiolingistik lazim didefinisikan sebagai cabang linguistik yang mempelajari hubungan dan saling pengaruh antara perilaku bahasa dan perilaku sosial (Kridalaksana, 2008:225). Dell Hymes 1973 (dalam Sumarsono, 2008: 3) mengatakan "Sociolinguistics could be taken to refer to use of linguistic and analysis in other discipline concerned with social life conversely, to use of social data and analysis in linguistics.

"Sosiolinguistik dapat mengacu kepada pemakaian data kebahasaan dan menganalisis ke dalam ilmu-ilmu lain yang menyangkut kehidupan social dan sebaliknya, mengacu kepada data kemasyarakatan dan manganalisis ke dalam linguistik. Berdasarkan kutipan di atas dapat dijelaskan bahwa sosiolinguistik menyangkut tiga hal yang penting, yakni bahasa, masyarakat, dan hubungan bahasa dengan masyarakat. Bahasa dan masyarakat merupakan satu kesatuan yang utuh dan tidak dapat terpisahkan. Bahasa sebagai sarana terpenting dalam berkomunikasi akan selalu hadir disetiap kebutuhan hidup manusia.

Bahasa gaul memang unik dan menggelitik masyarakat bahasa khususnya anak muda untuk menuturkannya. Dengan prinsip "semakin unik semakin menarik", bahasa gaul dapat menjadi virus yang sangat cepat menyebar dan negatifnya ialah kalau bahasa jenis itu sampai mengacaubalaukan standar bahasa Indonesia yang sesuai EYD. Tapi, lagilagi berbicara tentang arbitrerisasi bahasa. Bagaimanapun 'anehnya' bahasa jenis itu yang terkadang jauh dari konteks aslinya apalagi sering berbenturan dengan aturan EYD, bahasa jenis itu masih mempunyai banyak penutur yang meminati. Apalagi kalau ini sudah berkaitan dengan kreativitas. Menurut Chaer (2004: 61), sebuah bahasa mempunyai sistem dan subsistem yang dipahami oleh semua penutur bahasa. 
Namun, karena penuturbahasa tersebut, meski berada dalam masyarakat tutur, tidak merupakan kumpulan manusia yang homogen, maka wujud bahasa yang konkret(parole),menjadi tidak seragam. Bahasa pun menjadi beragam dan bervariasi.Variasi bahasa adalah wujud perubahan atau perbedaan dari berbagai manivestasi kebahasaan, namun tidak bertentangan dengan kaidah kebahasaan.

Dalam variasi bahasa, terdapat dua pandangan. Pertama, variasi dilihat sebagai akibat adanya keragaman sosial penutur bahasa dan keragaman fungsi bahasa. Jadi, variasi tersebut terjadi sebagai akibat dari adanya keragaman sosial dan keragaman fungsi bahasa.

Kedua, variasi atau ragam bahasa sudah ada untuk memenuhi fungsinya sebagai alat interaksi dalam kegiatan masyarakat yang beraneka ragam (Chaer, 2004: 62). Berbeda dengan Chaer, menurut Wardhaugh (1988: 22), variasi bahasa merupakan seperangkat khusus hal-hal mengenai linguistik atau pola tutur manusia, seperti bunyi, kata, dan ciri-ciri gramatikal.Pola tutur manusia tersebut secara unik dapat dihubungkan dengan faktor eksternal, seperti daerah geografi dan kelompok sosial. Kridalaksana (2008: 253) menyebut variasi bahasa sebagai satuan yang sekurang- kurangnya mempunyai dua variasi yang dipilih oleh penutur bahasa.Variasi tersebut tergantung dari faktor-faktor seperti jenis kelamin, umur, status sosial, dan situasi.

Variasi itu dianggap sistematis karena merupakan interaksi antara faktor sosial dan faktor bahasa.Variasi bahasa dari segi pemakai atau penutur menurut Chaer (2004:62--64) dapat dibedakan atas idiolek, dialek, kronolek, dan sosiolek. Idiolekadalah variasi bahasa yang bersifat perorangan. Dialek adalah variasi bahasa dari sekelompok penutur yang jumlahnya relatif, yang berada pada suatu tempat, wilayah, atau area tertentu. Dialek juga idefinisikan sebagai sub unit regional dalam kaitannya dengan satu bahasa, khususnya dalam logat aslinya atau realisasi ujarannya (Fishman via Alwasilah, 1985: 49). Kronolek adalah variasi bahasa yang digunakan oleh kelompok sosial pada masa tertentu. Sosiolek adalah variasi bahasa yang berkenaan dengan status, golongan, kelas sosial para penuturnya, seperti usia, pendidikan, seks, pekerjaan, keadaan ekonomi, dansebagainya.

Variasi bahasa dapat juga disebabkan oleh gaya. Joss (dalam Soeparno, 2002: 75) membedakan lima macam gaya berdasarkan tingkat kebakuannya. Kelima macam gaya tersebut sebagai berikut. a. Gaya Frozen Gaya ini juga disebut sebagai gaya beku karena pembentukannya tidak pernah berubah dari masa ke masa.b. Gaya Formal Gaya ini juga disebut sebagai gaya baku. Gaya ini digunakan padasituasi resmi.c. Gaya Konsultatif Gaya ini juga disebut sebagai gaya usaha, karena bentuknya terletak antara gaya formal dan informal. Gaya ini banyak dipergunakan dari kalangan bisnis. d. Gaya Kasual Gaya ini disebut juga gaya informal atau santai. Gaya ini menggunakan unsur leksikal dialek dan unsur daerah. e. Gaya Intim Gaya ini disebut juga sebagai gaya akrab karena biasanya dipergunakan olehpara penutur yang hubungannya sudah sangat akrab.

Menurut Suhardi (2008: 23), morfologi sebagai salah satu cabang Ilmu bahasa mengkaji masalah-masalah yang terkait dengan struktur kata. Dalam buku-buku Tata Bahasa Indonesia butirbutir yang dibicarakan dalam morfologi ialah masalah pembentukan kata dalam rangka penjenisan kata atau kelas kata, 
masalah bentuk dan jenis afiks imbuhan), dan masalah makna afiks.

\section{METODE PENELITIAN}

Penelitian ini merupakan penelitian deskriptif yang bertujuan untuk mendeskripsikan kosakata dalam bahasa gaul. Di dalam deskripsi tersebut,akan dijelaskan perubahan struktur fonologis kosakata bahasa gaul, proses pembentukan kosakata gaul secara morfologis, jenis makna yang terdapat dalam kosakata bahas gaul, dan fungsi penggunaan kosakata dalam bahasa gaul. Penelitian deskriptif hanya menggambarkan apa adanya tentang suatu variabel, gejala atau keadaan. Djadjasudarma (1993: 8) mengatakan bahwa penelitian deskriptif bertujuan untuk membuat deskripsi, yaitu untuk membuat gambaran, lukisan secara sistematis, faktual, dan akurat mengenai data, sifat-sifat serta hubungan fenomena yang diteliti.

Penelitian kualitatif didefinisikan sebagai suatu proses yang mencoba untuk mendapatkan pemahaman yang lebih baik mengenai kompleksitas yang ada dalam interaksi manusia (Catherine Marshal, 1995). Poerwandari (2007) mengungkapkan bahwa penelitian kualitatif menghasilkan dan mengolah data yang sifatnya deskriptif, seperti transkip wawancara, catatan lapangan, gambar, foto, rekaman video, dan lain sebagainya.

Penelitian ini menggunakan instrumen utama berupa pedoman observasi ke lapangan, sebagai langkah untuk pengambilan data yang akan diteliti. Pedoman observasi diturunkan dari kajian teori fonologi, morfologi, sintaksis dan fungsi penggunaan bahasa dengan menggunakan instrumen yang berupa seperangkat kriteria yang muncul pada bahasa gaul di kalanganpengguna bahasa gaul pasar dan terminal di Bojonegoro. Observasi dalam penelitian ini dilakukan dengan tujuan agar pada saat proses pengambilan data dapat melihat sendiri pemahaman yang tidak terucapkandan sudut pandang informan yang mungkin tidak terkuak melalui teknik simak, teknik, sadap, teknik cakap, teknik pancing, teknik catat. Kebenaran atau konfirmasi secara langsung kepada informan mengenai isivaliditas yang diragukan (Alwasilah, 2003: 172). Dari 10 informan dan pengambilan data dilaksanakan pada hari sabtu tanggal 10 Juli 2016 sampai 20 Juli 2016 di pasar dan terminal Bojonegoro tersebut dilakukan agar peneliti tidak meragukan validitas yang telah diperoleh.

\section{HASIL PENELITIAN DAN PEMBAHASAN}

Hasil penelitian dan pembahasan terhadap Ragam Bahasa Gaul di pasar dan di terminal . Hasil penelitian ini akan disajikan disertai dengan pembahasannya. Hasil penelitian diwujudkan dalam bentuk tabel-tabel yang diuraikan secara rinci dalam pembahasan. Berdasarkan penelitian terhadap bahasa gaul di pasar dan di terminal Bojonegoro diperoleh hasil penelitian berupa wujud kosakata bahasa gaul dalam perubahan struktur fonologis kosakata bahasa gaul dan pembentukan kosakata secara morfologis bahasa gaul di pasar dan terminal.

Penyajian hasil penelitian ditulis dalam bentuk pembahasan yang terdiri atas perubahan struktur fonologis bahasa gaul di pasar dan terminal Bojonegoro 1) perubahan struktur fonologis Bahasa gaul di pasar dan terminal Bojonegoro varian bahasa Indonesia dan 2) proses morfologis bahasa gaul di pasar dan terminal Bojonegoro. 


\section{Struktur Fonologis Kosa Kata Bahasa}

Gaul

Penghilangan vokal terakhir

(1) Mbak bel baju busana muslim. (bel $\rightarrow$ beli)

(2) Bismu maj dikit rajawali berangkat ke Surabaya (maj $\rightarrow$ maju)

\section{Penghilangan konsonan tengah}

(1) Ayo... pegi dong... (duduk.di ruang tunggu di terminal) (pegi $\rightarrow$ pergi)

(2) Aku tadi niak beak....ke terminal. (beak $\rightarrow$ becak)

\section{Penambahan vokal}

(1) iyai $\rightarrow$ iya $+\mathrm{i}=$ iyai, perubahan yang terjadi adalah menjadi diftong ai

(2) Seksai $\rightarrow$ seksi+a = seksai, perubahan yang terjadi adalah menjadi diftong ai.

\section{Penggantian vokal}

(1) ...due satowae or entek2! Op maneh telu!....(sato $\rightarrow$ satu)

(2) ...dasar gumek! Awas nek ngasi $1000 !$.... (gumek $\rightarrow$ gemuk)

\section{Penggantian konsonan}

(1) peanbifa pergi. (bifa $\rightarrow$ bisa)

(2) Afa yang kamu kerjakan. (afa $\rightarrow$ apa)

\section{Pemindahan konsonan}

(1) ...koroknya suruh matiin ndut! Nyesek! (korok $\rightarrow$ rokok)

(2).Aji sopir dali kisat,ya? (kisat $\rightarrow$ sakit)

Penambahan konsonan akhir kata dan pergantian vokal

(1) Dia jenjes sama sales wingsdi pasar (jen-jes $\rightarrow$ janji $=$ jenjes.)

(2) Kamu berangkat dari bojonegoro kele? (keles $\rightarrow$ kali)
Pemindahan vocal dan konsonan di akhir kata dipindah di tengah suku kata awal

(1) Ak gak kenalorgandi terminal....(organ $\rightarrow$ orang)

(2) Ia tunggu istinya sudah dukud satu jam. (dukud $\rightarrow$ duduk)

\section{Penambahan vokal}

(1) ...Aku boleh pinjam laipitoipimu?kembalikan....(laipitoip i $\rightarrow$ laptop)

(2) Penumpang itu lho cantike. (cantike $\rightarrow$ cantik)

Penggantian vokal dan konsonan

(1) Ana gitor gak ke pasar, keles? (gitor $\rightarrow$ tidur)

(2) Anakku sama ibunya menye. (menye $\rightarrow$ manja)

\section{Pemindahan vokal suku kata pertama} dan terakhir (metatesis)

(1) Niak dong ke bis (niak $\rightarrow$ naik)

(2) Kontak bismu uti di meja. (uti $\rightarrow$ itu)

Pembalikan (walikan) vokal dan konsonan

(1) Kamu kok tahes banget tho Wi !... (tahes $\rightarrow$ sehat)

(2) Bajumu yang kamu pakai sinam sekali. ( sinam $\rightarrow$ manis)

\section{Pembalikan suku kata}

(1) ... makan thu tacin! Wkwkwkk, (tacin $\rightarrow$ cantik)

(2) Mereka tidak raceboh berangkat mngendarai bis. (Raceboh $\rightarrow$ cerobah)

\section{Penghilangan suku kata terakhir}

(1) ...Man, nanti malam ron lho! (di terminal) (ron $\rightarrow$ ronda)

(2) Dia membuka toko lam pasar ramai. $($ lam $\rightarrow$ lambat) 
Penghilangan suku kata pertama

(1) ...Sampean. Ayuí. Sis Luna. (persis $\rightarrow$ sis)

(2) Penumpang suruh masuk nanti dibat bis belakang. (bat $\rightarrow$ hambat)

\section{Penggantian konsonan}

(1) ...mereka petiwu, uang aja yang dicari. (Pe-ni-pu $\rightarrow$ pe-ti$\mathrm{wu}=$ petiwu)

(2) Ia memang pantai. (pantai $\rightarrow$ pandai)

\section{Struktur Morfologis Bahasa Gaul} Akronim dibentuk dari dua suku awal/akhir dari dua kata

(1) ... Almas tulung kontak bis tu sekarang mager.... (males gerak).

(2) ... Jaka oleh raker ki critane...(raker $\rightarrow$ randa keren).

Akronim dibentuk dari dua kata

(1) ... welha, dasar pede kowe ki Nang(pede $\rightarrow$ percaya diri)

(2) Pembicarannya selalu baper.(baper $\rightarrow$ bawa perasaan)

\section{Akronim dibentuk dari empat suku awal} dari empat kata

(1) Dia Surur mesti milih sik pecegege.(pecinta cewek gemukgemuk)

(2) Ia pasti macan boro.( manis cantik bocah bojonegoro)

\section{Afiksasi}

(1) ...lho tho, terus munyukan Gas....(munyukan $\rightarrow$ munyuk/hewan)

(2) ...ahhh, Dia Cuma bisa cascisan tuh.(cascisan $\rightarrow$ cascis/hanya bisa ngomong)

\section{Reduplikasi sintaksis}

(1) ...bifa-bifa, tenang wae. Tad? (bifabifa $\rightarrow$ baisa-bisa)

\section{Reduplikasi fonologis}

(1) ... sik,nungguwek-wek. (di pasar) (wek-wek $\rightarrow$ bebek/motor)

Menambahkan sisipan-ok- pada tengah kata dan membuang huruf vocal dan atau konsonan di belakang kata

(1) "Heh bro, makokan nang coffe terminal kyeh.(makokan $\rightarrow$ makan)

(2) Dik bayokar kaos oblong ya...(di pasar)(bayokar $\rightarrow$ bayar)

\section{Penambahan akhir kata -ing dan} penghilangan vokal dan konsonan

(1) Gyeh bocah ciliktiding teyus.jare budal bimbingan (di pasar)(tiding $\rightarrow$ tidur)

Menambahkan sisipan-ok-pada tengah kata dan membuang huruf vocal dan atau konsonan di belakang kata

(1) “Aku takut dimarahibokape."di pasar(bapak $\rightarrow$ b+ok-ap = Bokap)

(2) Adik, moka? (moka $\rightarrow \mathrm{ma} / \mathrm{mama})$

\section{Penambahan akhir kata -ong dan} penghilangan vokal dan konsonan

(1) 'Kira- kira Bojonegoro ada bencong ya?' (banci $\rightarrow$ benc+ong=Bencong)

(2) Sampean akan merit dengan Jandong. (jendong $\rightarrow$ janda)

\section{Simpulan dan Saran}

Teori Zulfatu Nikmah (2012) tentang akronim, teori Sekar arum (2014) Ismiyati (2011) sama bedanya pembentukan secara morfologis pembalikan (walikan), sisipan-ok-, akhiran-ong Sedangkan penemuan peneliti akhiran -ing penghilangan vocal dan konsonan, sisipan -ok- dihilangkan vokal terakhir.

Hasil penelitian dan pembahasan tentang bahasa gaul masyakat pasar dan terminal, dapat disimpulkan sebagai berikut. Struktur fonologis kosakata 
dalam bahasa bahasa gaul di pasar dan di terminal adalah sebagai berikut.Pada varian bahasa Indonesia, perubahan struktur fonologis kosakata Bahasa bahasa gaul di pasar dan di terminal mengalami delapan perubahan yaitu 1) penghilangan vokal terakhir, 2) penghilangan konsonan tengah, 3) penambahan vokal, 4) pengantian vokal, 5) penggantian konsonan, 6) pemindahan konsonan, 7) penambahan konsonan akhir kata dan pergantian vokal, 8) Pemindahan vocal dan konsonan di akhir kata ditengah suku kata awal.

Pada varian bahasa Indonesia, perubahan struktur fonologis kosakata bahasa bahasa gaul di pasar dan di terminal mengalami sembilan perubahan yaitu 1) penambahan vokal, 2) penggantian vokal dan konsonan, 3) pemindahan vokal suku kata pertama dan terakhir, 4) pembalikan (walikan) vokal dan konsonan, 5) pembalikan suku kata, 6) penghilangan suku kata terakhir, 7) penghilangan suku kata pertama, 9) pemertahanan suku kata pertama dan konsonan pertama pada suku kata kedua, serta 9) penggantian konsonan.

Berdasarkan proses pembentukan secara morfologis kosakata Bahasa Gaul di pasar dan di terminal sebagai berikut. Proses pembentukan kosakata bahasa gaul varian bahasa indonesia secara morfologis mengalami tiga proses yaitu afiksasi, reduplikasi, dan akronim yang terdiri atas tiga varian yaitu dibentuk dari dua suku awal/akhir dari dua kata, akronim dibentuk dari dua suku awal dari dua kata, akronim dibentuk dari empat suku awal dari empat kata, .Menambahkan sisipan -ok- pada tengah kata dan membuang huruf Vocal dibelakang kata. Penambahan akhir kata -ing dihilangakan Vokal dan Konsonan

Proses pembentukan kosakata bahasa gaul varian bahasa Indonesia secara morfologis mengalami tiga proses, yaitu akronim, afiksasi dan reduplikasi. Akronim pada bahasa gaul varian bahasa Indonesia yaitu yang dibentuk dari dari satu suku awal tiap masing-masing kata, Menambahkan sisipan-ok- pada tengah kata dan membuang huruf Vocal dan atau konsonan di belakang kata. Penambahan akhir kata -ong dihilangakan vokal dan konsonan.

Bagi pembaca, mahasiswa dan guru, penelitian tentang bahasa gaul ini dapat memberikan tujuan tambahan wawasan yang lebih luas mengenai bahasa gaul. Bahwa bahasa gaul merupakan salah satu varian bahasa gaul yang diminati para pengguna bahasa gaul di pasar dan di terminal. Oleh karena itu, pembaca dapat diberikan manfaat gambaran, interpretasi proses fomologi, morfologi dan sintaksis yang lebih kreatif dan menciptakan lebih banyak lagi kosakata dalam bahasa gaul.

Bagi para peneliti, penelitian tentang bahasa gauldi pasar dan terminal masih sangat sederhana dan jauh dari sempurna. Masih banyak masalahmasalah yang belum diteliti. Misalnya batasan waktu bahasa digunakan, dan faktor-faktor lain mengenai bahasa gaul. Selain hal itu, dapat pula dilakukan penelitian yang lebih mendalam. Sebab, ada daerah lain Bahasa Gaul di pasar dan di terminal selain daerah Kitren yang menggunakan bahasa prokem, sebagai contoh adalah daerah Bahasa Gaul di pasar dan di terminal a Bojonegoro

\section{DAFTAR RUJUKAN}

Muslich, Masnur.2008 Fonologi Bahasa Indonesia Tinjauan Diskriptif Sistem Bunyi Bahasa Indonesia Edisi Keenam Jakarta: Bumi Aksara 
Anwar, Khaidir. 1984. Fungsi Dan Peranan Bahasa: Sebuah Pengantar. Yogyakarta: Gajah Mada University Press.

Arikunto, Suharsini. 1987. Prosedur Penelitian Suatu Pendekatan Praktik. Jakarta: Bina Aksara.

2004. Sosiolinguistik Perkenalan Awal. Jakarta: Rineka Cipta.

---------. 1998. Tata Bahasa Praktis Bahasa Indonesia. Jakarta: Rineka Cipta.

Holmes, J. 1995. An Introduction to Sociolinguistics. New York: Logman.

Kridalaksana, Harimurti. 2008. Kamus Linguistik Edisi Keempat. Jakarta: PT. Gramedia.

2007. Pembentukan Kata dalam Bahasa Indonesia. Jakarta: Gramedia.

Mahsun. 2005. Metode Penelitian Bahasa. Jakarta: PT Raja Grafindo.

Mohhamad, Atqo. 2010. "Perkembangan Bahasa Gaul di Indonesia". http: Aqto

Muhammad.blogt.spot.com/2010/0

3. Diunduh pada 4 Maret 2011.

Moleong, Lexy. 1989. Metode Penelitian Kualitatif. Bandung: Rosdakarya. 98

Muslich, Masnur. 2010. Fonologi Bahasa Indonesia. Jakarta: Bumi Aksara.

Ramlan, M. 2001. Morfologi Suatu Tinjauan Deskripstif. Yogyakarta:Karyono.

Sugono, D., dkk. 2008. Kamus Besar Bahasa Indonesia Pusat Bahasa. Edisi Keempat. Jakarta: PT Gramedia Pustaka Utama.
Suhardi. 2008. Sintaksis. Yogyakarta: Uny Press.

Suparno. 2002. Dasar-dasar Lingusitik Umum. Yogyakarta: PT. Tiara wacana.

Wardhaugh, R. 1988. An Introduction to Sociolinguistics. New York: Basil Blackwell.

Yasin, Sulcan. 1987. Tinjaun Deskriptif Seputar Morfologi. Surabaya: Usana Offset Printing.99

Zaka, Isfatun. 2010. "Karakteristik Leksikon Bahasa Gaul dalam Facebook". Skripsi. Universitas Negeri Yogyakarta.

Zul, Eka. 2009. "Pemakaian BahasaProkem”,http://id.wikipedia. org/wiki/Bahasa Prokem Indonesia/.Diunduh pada tanggal 13 Maret 2016.

Ismiyati. 2012 Bahasa Prokem dai Kalangan Remaja Kotagede, Skripsi Universitas Negeri YogyakartaDiunduh pada tanggal 18 Maret 2016

Mekyke.2013.Penggunaan KosaKata Alay oleh Remaja pada Facebook di kota Bengkulu.Tesis

Universitas Bengkulu Diunduh pada tanggal 15 Maret 2016

Arum Asmara Noehilasari, Sekar .2014. Periodisasi dan Proses Pembentukan Kosa Kata Bahasa Gaul Tahun 1990-2012.Skripsi Universitas Negeri Yogyakarta Diunduh pada tanggal 11 Maret 2016

Nikmah, Zulfatu. 2012. Analisis Akronim Gaul pada Wacana Striker. Skripsi Universitas Muhammadiyah Surakarta 
Aplikasi Kamus Gaul Keren di Android.

Diunduh pada tanggal 15 Maret 2016. 